\title{
触 New Disease Reports \\ First report of Grapevine fanleaf virus infecting grapevine in the United Kingdom
}

\author{
G. Silva ${ }^{1}{ }^{*}$, J. Lecourt ${ }^{2}$, G.R.G. Clover $^{3}$ and S.E. Seal ${ }^{1}$ \\ ${ }^{1}$ Natural Resources Institute, University of Greenwich, Chatham Maritime, Kent ME4 4TB, UK; ${ }^{2}$ NIAB EMR, New Road, East \\ Malling, Kent ME19 6BJ, UK; ${ }^{3}$ Royal Horticultural Society, RHS Garden Wisley, Woking, Surrey GU23 6QB, UK
}

*E-mail: g.silva@gre.ac.uk

Received: 15 Aug 2017. Published: 25 Sep 2017. Keywords: detection, GFLV, Vitis vinifera

The UK wine industry is a fast-growing sector and in 2015 an area of c. 2,000 hectares had been planted with vines from which over five million bottles of wine were produced (Wine and Spirit Trade Association Market Overview, 2016). It is important to monitor the phytosanitary status of vines to ensure the sustainability of the industry in the UK.

In April 2017, four samples were collected. These were one dormant cane, selected at random, from each of four geographically separated vineyards which were from Pinot Noir clones $(119,336,792$ and 924) reciprocally grafted upon Gravesac, SO4 or 3309 Couderc rootstocks. RNA was extracted from cambial scrapings using a modified CTAB method previously described by Abarshi et al. (2010) and tested using specific primers for nine grapevine viruses by RT-PCR (Gambino \& Gribaudo 2006). All samples tested positive for Grapevine rupestris stem pittingassociated virus (GRSPaV) and two of the samples, clones 119 and 792, had mixed infections with Grapevine fleck virus (GFkV) and Grapevine fanleaf virus (GFLV), respectively.

PCR amplicons from GRSPaV and GFkV primer sets were sequenced in both directions, and similarity searches using BLAST in the GenBank databases showed that the GFkV sequence (GenBank Accession No. MF959546) has 97\% nucleotide identity with isolate SK79 from Slovakia (JN133946), and GRSPaV sequences (MF959547 to MF959550) have 97 to $100 \%$ nucleotide identity with isolates from Italy (DQ278627, HE591388 and FN555301) and the UK (KP284454).

To confirm the detection of GFLV in the UK on Pinot Noir clone 792 a second RT-PCR was performed using GFLV-specific primers targeting the coat protein (CP) of the virus (Mekuria et al., 2008). An amplicon of the expected size (322 bp) was obtained and sequenced in both directions. BLAST searches revealed that the obtained sequence (MF576058) showed 92\% nucleotide identity with the homologous CP region of GFLV isolates (DQ362924 and DQ362933) from Italy.

To our knowledge, this is the first report of GFLV in the UK. GFLV is responsible for fanleaf degeneration disease, one of the most damaging viral diseases of grapevine (Andret-Link et al., 2004) causing malformation of leaves and affecting fruit quality and yield. Immanuel et al. (2015a; 2015b) previously reported the presence of GFkV, GRSPaV, Grapevine leafroll-associated virus 1 and Grapevine virus $A$ infecting grapevine in the UK. The presence of viruses from different genera (Ampelovirus, Foveavirus, Maculavirus, Nepovirus and Vitivirus) constitutes a threat to the UK's developing grapevine industry. Large scale surveys of commercial vineyards in the UK are needed to determine the presence and incidence of grapevine viruses and to evaluate their potential effects on vineyard productivity and fruit yields and quality.

\section{References}

Abarshi MM, Mohammed IU, Wasswa P, Hillocks RJ, Holt J, Legg JP, Seal SE, Maruthi MN, 2010. Optimization of diagnostic RT-PCR protocols and sampling procedures for the reliable and cost-effective detection of Cassava brown streak virus. Journal of Virological Methods 163, 353-359. http://dx.doi.org/10.1016/j.jviromet.2009.10.023

Andret-Link P, Laporte C, Valat L, Ritzenthaler C, Demangeat G, Vigne E, Laval V, Pfeiffer P, Stussi-Garaud C, Fuchs M, 2004. Grapevine fanleaf virus: Still a major threat to the grapevine industry. Journal of Plant Pathology 86, 183-195. http://dx.doi.org/10.4454/jpp.v86i3.987

Gambino G, Gribaudo I, 2006. Simultaneous detection of nine grapevine viruses by multiplex reverse transcription-polymerase chain reaction with coamplification of a plant RNA as internal control. Phytopathology, 1223-1229. http://dx.doi.org/10.1094/PHYTO-96-1223

Immanuel T, Delmiglio C, Ward LI, Denton JO, Clover GRG, 2015a. First reports of Grapevine virus A, Grapevine fleck virus and Grapevine leafrollassociated virus 1 in the United Kingdom. Plant Disease 99, 898.

http://dx.doi.org/10.1094/PDIS-12-14-1273-PDN

Immanuel T, Delmiglio C, Ward LI, Denton JO, Clover GRG, 2015b. Grapevine rupestris stem pitting-associated virus detected in Vitis vinifera in the United Kingdom. New Disease Reports 31, 10. http://dx.doi.org/10.5197/j.2044-0588.2015.031.010

Mekuria TA, Martin RR, Naidu RA, 2008. First report of the occurrence of Grapevine fanleaf virus in Washington State vineyards. Plant Disease 92, 1250. http://dx.doi.org/10.1094/PDIS-92-8-1250A

To cite this report: Silva G, Lecourt J, Clover GRG, Seal SE, 2017. First report of Grapevine fanleaf virus infecting grapevine in the United Kingdom. New Disease Reports 36, 9. http://dx.doi.org/10.5197/j.2044-0588.2017.036.009 